\title{
RADIOCARBON AND THERMOLUMINESCENCE STUDIES OF THE KARST PIPE SYSTEMS IN SOUTHWEST ENGLAND AND SOUTH WALES
}

\author{
MIECZYSEAW F. PAZDUR, ${ }^{1,2}$ ANDRZEJ BLUSZCZ, ${ }^{1}$ ANNA PAZDUR ${ }^{1}$ and \\ IWONA MORAWIECKA ${ }^{3}$
}

\begin{abstract}
Paleokarst forms in raised beach deposits of Southwest England and South Wales and generally known as "pipes" were dated by ${ }^{14} \mathrm{C}$ and thermoluminescence (TL) methods. Current geological opinion is that these pipes are features that developed under the cover of periglacial-solifluctional deposits due to periglacial conditions prevalent in the Late Devensian. In the present study, TL was used to determine the age of quartz grains forming the raised beaches. ${ }^{14} \mathrm{C}$ ages were obtained from carbonate cements within sandrock and on the pipe walls. TL ages measured for quartz grains separated from sandrock samples are older than $80 \mathrm{ka} \mathrm{BP}$, whereas the corresponding TL dates obtained from the sandy material of pipe infills center around $40 \mathrm{ka} \mathrm{BP}$. All carbonates yielded finite apparent ${ }^{14} \mathrm{C}$ dates that range from ca. $45 \mathrm{ka} \mathrm{BP}$ to $27 \mathrm{ka}$ BP for sandrock. The apparent ${ }^{14} \mathrm{C}$ dates obtained on carbonate cements from the pipe walls fall into two groups, one ranging from $30 \mathrm{ka} B P$ to $22 \mathrm{ka} \mathrm{BP}$ and the other from $15 \mathrm{ka} \mathrm{BP}$ to $7 \mathrm{ka} \mathrm{BP}$. On the basis of geochemical considerations, we conclude that the sandrock cements formed between 35 and $25 \mathrm{ka}$ BP and pipe walls cemented between 30 and $2 \mathrm{ka}$ BP with a break during the climate deterioration caused by last ice sheet advance.
\end{abstract}

\section{INTRODUCTION}

The semi lithified calcareous sandstones and arenaceous limestone of the Pleistocene raised beaches of Southwest England and South Wales are generally known as "sandrock". These deposits feature some karst development, for the most part as vertical pipes. Most of these vertical pipes are neatly cylindrical and are quite common in certain sites (Fig. 1).

Most authors associate the occurrence of pipes with karst processes, but so far scant attention has been given to the age and geochemical processes responsible for the development of these raised beach features. The most detailed and recent discussion is that of Morawiecka (1993), in which she concludes that: 1) pipes are paleokarst forms that developed under the cover of head deposits during the Late Devensian; and 2) periglacial conditions played an important role in determining their formation and geographical distribution.

The term "raised beach" derives from the earliest studies of the Pleistocene sediments of Southwest Britain. At that time all the sandy sediments underlying head deposits were considered to be of marine origin. It is now generally agreed that at least the upper parts of the raised beach deposits are eolian features (West 1973; Stephens 1970; Greenwood 1972) and that they are associated with eolianites (Morawiecka 1993). The average raised beach sandrock contains $51 \%$ calcium carbonate; therefore it is classified as a sandy limestone. All of the raised beaches discussed here rest on rock platforms up to $20 \mathrm{~m}$ thick and rise landward to about $8 \mathrm{~m}$ asl.

The raised beach formations along this coastline are invariably capped by up to $20 \mathrm{~m}$ of head deposits that accumulated as a consequence of various periglacial mass movements during the cold phases of the Pleistocene (Harris 1987). In geomorphological terms, these deposits are composed of the weathering products of local rocks, usually in the form of angular fragments dispersed in a silty and/ or sandy matrice. Recent studies (Scourse 1987, 1991) conclude that the main phases of head formation occurred during the Middle and Late Devensian.

\footnotetext{
${ }^{1}$ Department of Radioisotopes, Silesian Technical University, Krzywoustego 2, PL-44-100 Gliwice, Poland

2Deceased 11 May 1995

${ }^{3}$ Department of Geomorphology, Silesian University, Bedzinska 60, PL-41-200 Sosnowiec, Poland
} 


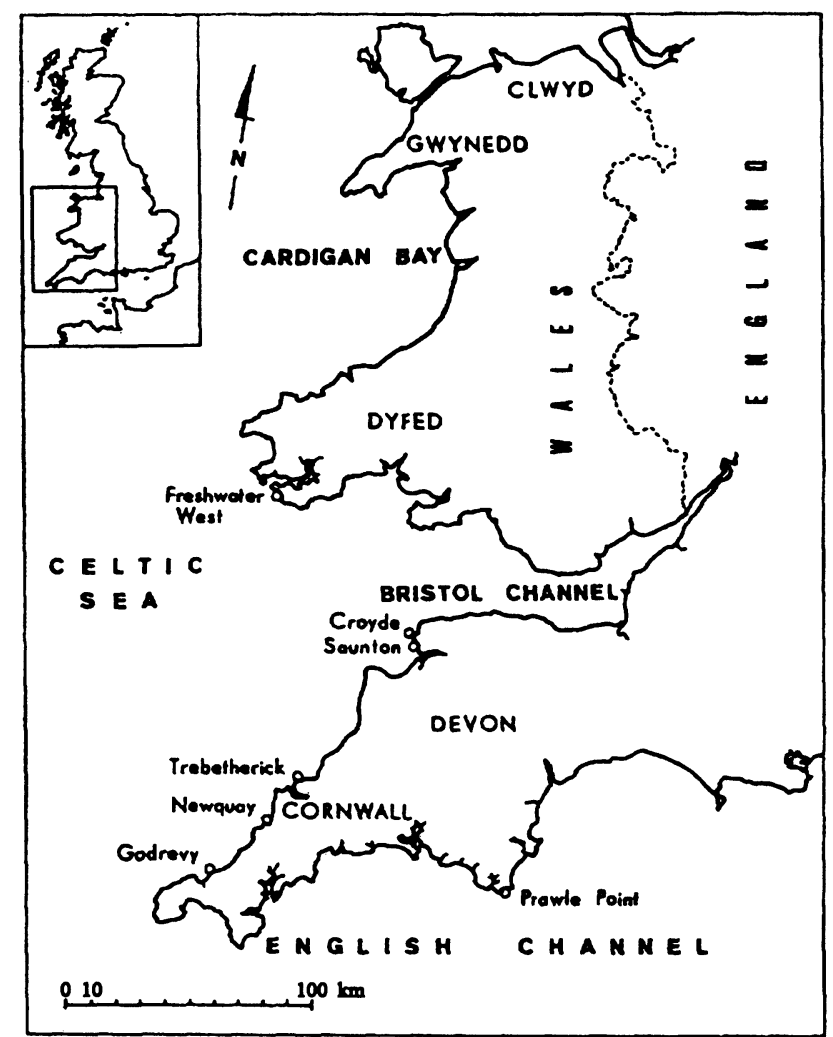

Fig. 1. Study area. $0=$ the raised beach sections studied. They include the Quaternary cliffs of Cornwall (Newquay, Trebetherick, Godrevy), Devon (Saunton, Croyde, Prawle Point) and S Wales (Freshwater Point).

\section{GENERAL BACKGROUND}

A total of 586 pipes were recorded at the 7 sites studied in SW British coast (Fig. 1). The individual sections studied are very similar in many respects but each site has its own distinctive features. In almost all instances the pipes occur as semi-open cylinders in the cliff wall.

The mean total carbonate content of raised beach sandrock at each site ranges from 61 to $37 \%$ with an average value of $51.5 \%$ (the rest is mainly quartz sand), which classifies the typical host rock as an arenaceous limestone. Those sections in which the carbonate content is higher than $50 \%$ (Godrevy, Prawle Point, Saunton, Croyde and Hope's Nose) are regarded as limestones, whereas the others (Newquay, Trebetherick, Freshwater West) are calcareous sandstones. The carbonate content in the pipe walls is slightly higher than that of the surrounding sandrock, which suggests that they are doubly cemented, or cemented several times. The pipe infills are free from carbonates, which is evidence that the pipes originated through dissolution-based processes (Morawiecka 1993).

The carbonate component of the host rock is mainly cemented molluscan debris. The cement of the host rock, termed stage 1 cement by West (1973), consists of isometric, sparry, low-magnesium calcite, which is irregularly distributed on a microscopic scale. The cemented material forms very irregular nodules between which there are inseminated sands that resemble tubulus. Minor occurrences of 
low-magnesium calcite cement (stage 2 cement) are associated with pipes. This stage 2 cement was produced by the deposition of carbonate dissolved during formation of the pipes (West 1973).

\section{METHODS AND RESULTS}

\section{Radiocarbon Measurements}

${ }^{14} \mathrm{C}$ age determinations were based on the total carbonate in samples collected from pipe walls or from the surrounding rock. ${ }^{14} \mathrm{C}$ activity was monitored using proportional counters filled with pure carbon dioxide. The results of carbon isotope measurements are listed in Table $1 .{ }^{14} \mathrm{C}$ dates are quoted as conventional ${ }^{14} \mathrm{C}$ years BP, according to Stuiver and Polach (1977), i.e., the age calculations incorporate normalization of the measured ${ }^{14} \mathrm{C}$ enrichment to equate with $\delta^{13} \mathrm{C}(\mathrm{PDB})=-25 \%$ as compensation for isotopic fractionation effects.

TABLE $1 .{ }^{14} \mathrm{C}$ and ${ }^{13} \mathrm{C}$ in Carbonates

\begin{tabular}{lccl}
\hline Sample & Lab no. & $\begin{array}{c}{ }^{14} \mathrm{C} \text { age } \\
\text { (years BP } \pm 1 \text { o) }\end{array}$ & $\begin{array}{l}\delta^{13} \mathrm{C} \\
(\mathrm{PDB}, \% \text { ) }\end{array}$ \\
\hline Pipes & & & \\
C209 & Gd-3631 & $24,700 \pm 170$ & -5.2 \\
C101 & Gd-7391 & $26,200 \pm 200$ & $(-6.0)^{*}$ \\
C201 & Gd-7392 & $47,000 \pm 2550$ & $(-6.0)$ \\
F1 & Gd-7389 & $7250 \pm 70$ & -6.0 \\
F2 & Gd-6877 & $9420 \pm 120$ & -6.0 \\
F2 & Gd-6923 & $12,560 \pm 130$ & $(-6.0)$ \\
G102 & Gd-3635 & $29,500 \pm 220$ & -0.8 \\
N101 & Gd-3637 & $16,620 \pm 130$ & -3.0 \\
N101A & Gd-7342 & $12,380 \pm 180$ & -1.0 \\
N201 & Gd-7347 & $11,800 \pm 110$ & -2.2 \\
PP204 & Gd-3638 & $33,100 \pm 270$ & -5.6 \\
PP104 & Gd-7344 & $27,900 \pm 300$ & -5.9 \\
PP103 & Gd-6930 & $37,200 \pm 1300$ & $(-6.0)$ \\
S209U & Gd-3633 & $22,520 \pm 150$ & -2.6 \\
S208L & Gd-3632 & $29,400 \pm 200$ & -0.4 \\
S207V & Gd-3634 & $27,400 \pm 200$ & -4.7 \\
S303 & Gd-3676 & $15,280 \pm 120$ & $(-6.0)$ \\
T3 & Gd-7394 & $7030 \pm 70$ & $(-6.0)$ \\
T204 & Gd-3636 & $8830 \pm 70$ & -5.4 \\
Sandrocks & & & \\
C206 & Gd-7339 & $30,700 \pm 400$ & -6.0 \\
C210 & Gd-3678 & $38,370 \pm 850$ & $(-6.0)$ \\
F3 & Gd-6921 & $33,200 \pm 800$ & $(-6.0)$ \\
G207 & Gd-7335 & $28,500 \pm 300$ & -1.6 \\
N202 & Gd-7338 & $33,050 \pm 500$ & -0.1 \\
PP0 & Gd-3677 & $40,100 \pm 1100$ & $(-6.0)$ \\
PP205 & Gd-6878 & $24,500 \pm 300$ & -5.4 \\
S203 & Gd-7340 & $34,900 \pm 650$ & -2.6 \\
S204 & Gd-7345 & $33,200 \pm 500$ & -2.6 \\
T205 & Gd-7393 & $35,300 \pm 600$ & $(-6.0)$ \\
Mollusca & & & \\
C7 & & & +3.0 \\
PP12 & & & -2.5 \\
\hline
\end{tabular}

*Parentheses indicate assumed values 
The ${ }^{14} \mathrm{C}$ dates listed in Table 1 are "apparent ages" insofar as they obviously do not record the actual time since carbonate deposition. The dated carbonate samples may be divided into two groups: the first comprises samples collected from natural outcrops, the second represents samples collected from pipe walls. In the first group the carbonate contains geologically old $\left({ }^{14} \mathrm{C}\right.$-free) shell detritus and cement formed by the dissolution of shell and its subsequent precipitation as carbonate. The carbonate present in the samples of second group contains old shell detritus, carbonate cement of the first generation, and second-generation carbonate cement formed by dissolution of both shells and the primary cement. In both primary and secondary cements, the main source of ${ }^{14} \mathrm{C}$ is atmospheric $\mathrm{CO}_{2}$ dissolved in the water infiltrating the sandrock.

Both groups of dated carbonate samples contain old shell detritus and cements in approximately the same proportion. The mean composition of this carbonate is listed in Table 2 . These data indicate that for samples collected from pipe walls, an appropriate dilution coefficient " $q$ " may be estimated to be $c a$. 0.4 , whereas a value of $c a .0 .5$ applies for sandrock. These values correspond to the reservoir corrections of $c a .5000 \mathrm{yr}$ and $5500 \mathrm{yr}$, respectively. We assume, therefore, that the values of apparent ${ }^{14} \mathrm{C}$ ages listed in Table 1 are $c a .5500 \mathrm{yr}$ older than the true age of cementation. This estimation is valid provided the assumption holds that the duration of the cementation process is short compared to the age of the cement and, moreover, that the contribution from old carbon is similar for all samples.

TABLE 2. Characteristics of Carbonate Fractions in Defined Samples

\begin{tabular}{lll}
\hline & Sandrock & Pipes \\
\hline Carbonate content & $50 \%$ & $60 \%$ \\
Sediment composition & $\mathrm{M}+\mathrm{C} 1$ & $\mathrm{M}+\mathrm{C} 1+\mathrm{C} 2$ \\
Relative abundance & $(25 \%+25 \%)$ & $(20 \%+20 \%+20 \%)$ \\
"q" value & ca. 0.5 & $\mathrm{ca} .0 .4$ \\
$\mathrm{t}[\mathrm{yr}]$ & $\mathrm{ca} .5500$ & $\mathrm{ca} .5000$ \\
$<\delta^{13} \mathrm{C}>$ & $-3.05 \pm 0.78$ & $3.75 \pm 0.60$ \\
$\mathrm{r}\left(\delta^{13} \mathrm{C}, \mathrm{T}\right)$ & -0.33 & 0.18 \\
\hline
\end{tabular}

$\mathrm{M}=$ Mollusca, $\mathrm{C} 1=$ primary cement, $\mathrm{C} 2=$ secondary cement, $\mathrm{t}=$ reservoir correction $<>=$ mean value, $\mathrm{r}=$ correlation coefficient

The latter assumption in the case of samples of the first group means that 1) the sedimentation cycle was similar in all sites studied; 2) the contribution of old shell detritus is similar in all samples dated; and 3) the initial isotopic composition of shell detritus was the same.

In the case of samples of the second group, i.e., those collected from pipe walls and containing second-generation cements, it should be assumed also that their sedimentation cycle was similar to that which produced the primary cements.

A lack of significant correlation between values of uncorrected carbonate ages $\mathrm{T}$ and $\delta^{13} \mathrm{C}$ in both groups of samples (with correlation coefficient equal to -0.33 and 0.18 for the first and second groups of samples respectively; see Table 2) indicate a purely random scatter of stable isotopic composition for carbon in the dated samples. The correlation is insignificant between the age of samples and location of the study sites. The observed scatter of $\delta^{13} \mathrm{C}$ values is relatively high; for samples from the pipe walls it equals $1.96 \%$ and for samples from sandrock it equals $1.34 \%$.

\section{THERMOLUMinESCENCE DATING}

Material submitted to the laboratory represented two types of sediment: the sandrock cemented with reworked shell calcite, and loose sand from karst pipe forms. All samples underwent the standard 
treatment procedures (Bluszcz and Pazdur 1985). After the necessary radioactivity measurements were taken to determine the natural dose rate, we extracted quartz grains of $90-100 \mu \mathrm{m}$ diameter from the bulk sediment for TL dating.

The total dose rate was determined using a multichannel gamma scintillation spectrometer. Concentrations of the radioisotopes $\mathrm{U}$, Th and $\mathrm{K}$ were derived from the recorded spectra and converted to the values of annual dose rates appropriate for each sample (Aitken 1983). An attenuation effect of etching was taken into account (Fleming 1979; Mejdahl 1979) and an appropriate allowance made for cosmic ray contributions (Yokoyama et al. 1982). The average water content for the whole burial period is also an important consideration because water present in the sediment absorbs a fraction of radiation energy and effectively reduces the dose delivered to the grains. Most likely, the sandrock had no significant water content in the past since calcite cement filled all the intergranular space. On the other hand, the sand material filling karst pipe forms probably retained a significant water content, and thus the doses to mineral grains in these materials probably represent a considerable overestimate, while TL dating results are underestimated.

Equivalent values of total dose (ED) were obtained for all samples by the regeneration method. Table 3 lists experimental results and the corresponding TL age estimates. The sandrock samples are likely to have yielded the better estimate of time elapsed since the original sedimentation; during the secondary processes of cementation and karst erosion the grains were not exposed to sunlight. The grains in the pipe sample probably derive from the eroded sandrock and would not have been bleached by sunlight at that time; the unknown but suspected high humidity will have made calculated TL ages erroneously young, so these values do not record the time of pipe formation.

TABLE 3. Results of TL Dating

\begin{tabular}{lcccc}
\hline Sample & Lab no. & $\begin{array}{c}\text { Dose } \\
(\mathrm{Gy} / \mathrm{kg})\end{array}$ & ED (Gy) & $\begin{array}{c}\text { TL age } \\
(\mathrm{ka} \mathrm{BP})\end{array}$ \\
\hline Pipes & & & & \\
G & GdTL-390 & $2.72 \pm 0.17$ & $130 \pm 10$ & $48 \pm 5$ \\
PP & GdTL-391 & $1.02 \pm 0.08$ & $34 \pm 6$ & $34 \pm 7$ \\
PP104 & GdTL-392 & $0.52 \pm 0.06$ & $23 \pm 5$ & $44 \pm 11$ \\
Sandrock & & & & \\
F1 & GdTL-383 & $1.21 \pm 0.09$ & $90 \pm 20$ & $74 \pm 18$ \\
F2 & GdTL-389 & $0.86 \pm 0.10$ & $58 \pm 6$ & $67 \pm 11$ \\
N201 & GdTL-384 & $1.45 \pm 0.10$ & $100 \pm 30$ & $69 \pm 22$ \\
PP204 & GdTL-385 & $0.62 \pm 0.06$ & $72 \pm 9$ & $116 \pm 20$ \\
\hline
\end{tabular}

\section{DISCUSSION AND CONCLUSION}

The ${ }^{14} \mathrm{C}$ and $\mathrm{TL}$ datings of the selected sandrock, pipe wall and pipe infill samples (see Fig. 2) were carried out to construct a time scale for the following sequence of paleoenvironmental events in Southwest England and South Wales: raised beach formation, raised beach cementation and the formation of karst pipes within the raised beach deposits.

${ }^{14} \mathrm{C}$ measurements indicate that pipe-formation processes (i.e., the age of the pipe walls) generally postdate cementation of the host rock. The age of pipe wall carbonate falls in the range 37 to $7 \mathrm{ka}$ $\mathrm{BP}$, whereas the age of the host rock is in the range ca. 47 to $24 \mathrm{ka} \mathrm{BP}$. The pipes, therefore, are not coeval with the host rock, but are distinctly younger. However, the determined ages cannot be regarded as absolute values, either for host rock cementation or for the depositional pipe wall secondary cement. On the basis of ${ }^{14} \mathrm{C}$ dating and irrespective of compositional uncertainty, the pipe 


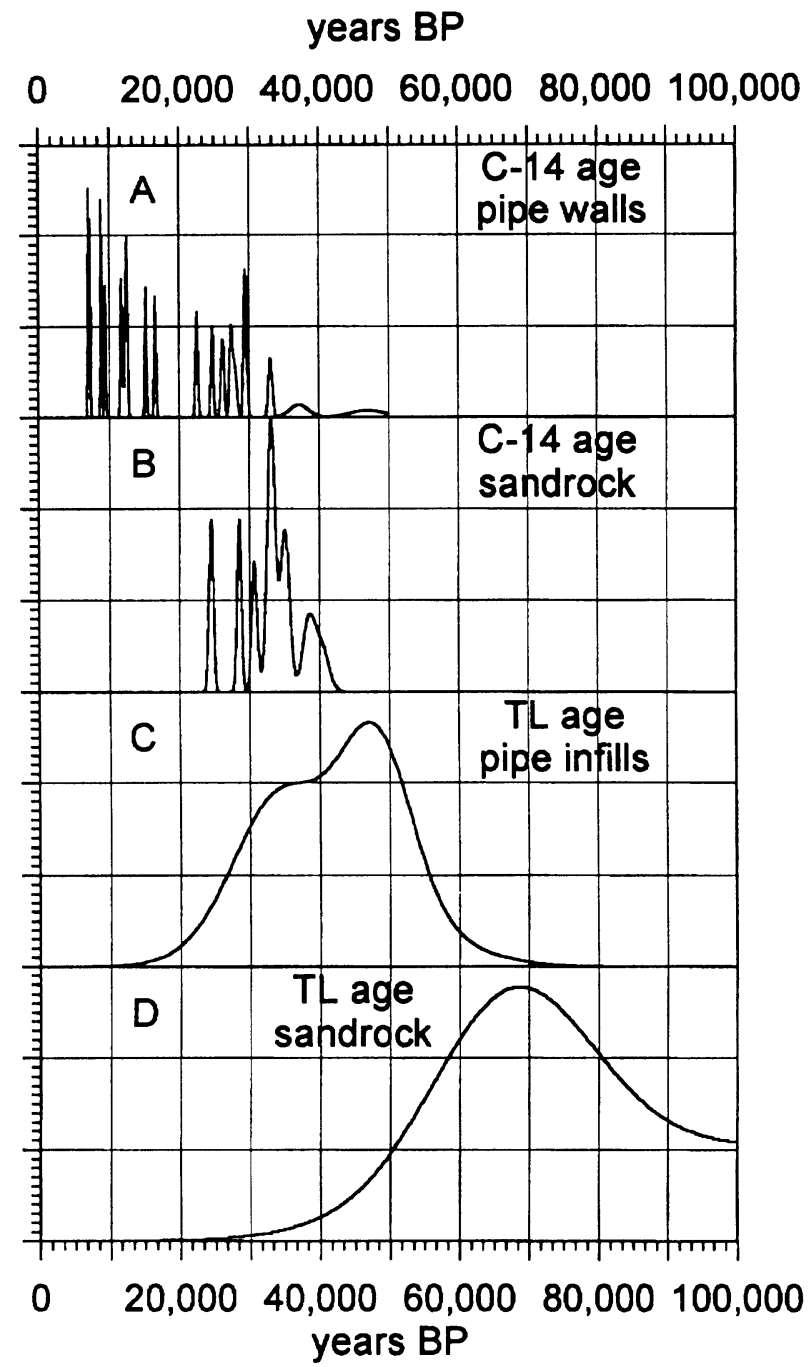

Fig. 2. Probability distribution of ${ }^{14} \mathrm{C}$ and TL ages. Maxima of the distribution determine periods on the time axis: curve $\mathrm{D}$ (TL data)—raised beaches formation; curves $\mathrm{A}$ and $\mathrm{B}\left({ }^{14} \mathrm{C}\right.$ data)-primary cementation and piping process; curve $\mathrm{C}$ (TL data)—apparent TL ages for pipe infills.

features are clearly younger than the Ipswichian interglacial-valuable evidence that they are all coeval and of Late Devensian age (probably close to or at the Pleistocene/Holocene boundary). Primary cementation of the raised beach probably relates to events in the Middle Devensian.

TL dating results suggest that the placement of raised beach deposits occurred sometime prior to 100 $\mathrm{ka}$ and up to $40 \mathrm{ka}$ BP. The measured TL ages of the pipe infill samples show that they come from between $34 \mathrm{ka} \mathrm{BP}$ and $48 \mathrm{ka}$ BP. This age pattern indicates that the pipe infills represent younger sediment, different from the raised beach host rock.

Although the raised beaches are traditionally accepted to be of Ipswichian age (135-115 ka BP), more recent determinations based on amino-acid geochronology (Bowen et al. 1985) suggest that 
the different raised beaches are not coeval and that in some cases their ages range beyond the Ipswichian boundaries. This hypothesis is supported by the present research.

\section{ACKNOWLEDGMENTS}

This study was supported by the State Committee for Scientific Research through grant PB 740/6/91, the Silesian University, and the Radiocarbon Foundation in Gliwice.

\section{REFERENCES}

Aitken, M. J. 1983 Radioactivity data using SI units. PACT 9: 65-71.

Bluszcz, A. and Pazdur, M. F. 1985 Comparison of TL and C-14 dates of young eolian sediments $-\mathrm{a}$ check of the zeroing assumption. Nuclear Tracks 10: 703-710.

Bowen, D. Q., Sykes, G. A., Reeves, A., Miller, G. H., Andrews, J. T., Brew, J. S. and Hare, P. E. 1985 Amino acid geochronology of raised beaches in South West Britain. Quaternary Sciences Reviews 4: 279-318.

Fleming, S. J. 1979 Thermoluminescence Techniques in Archaeology. Oxford, Clarendon Press: 233 p.

Greenwood, B. 1972 Modern analogues and the evaluation of a Pleistocene sedimentary sequence. Transactions of the Institute of British Geographers 56: 145167.

Harris, C. 1987 Solifluction and related periglacial deposits in England and Wales. In Broadman, J., ed., Periglacial Processes and Landforms in Britain and Ireland. Cambridge, Cambridge University Press: 209-223.

Mejdahl, V. 1979 Thermoluminescence dating: Betadose attenuation in quartz grains. Archaeometry 21: 61-72.

Morawiecka, I. (ms.) 1993 The nature and origin of paleokarst phenomena in Late Quaternary calcareous sandrock with special reference to the coasts of SW
England and S Wales. Ph.D. dissertation, Silesian University, Sosnowiec.

Pazdur, A. 1988 The relation between carbon isotope composition and apparent age of fresh-water tufaceous sediments. Radiocarbon 30(1): 7-18.

Scourse, J. D. 1987 Periglacial sediments and landforms in the Isles of Scilly and West Cornwall. In Broadman, J., ed., Periglacial Processes and Landforms in Britain and Ireland. Cambridge, Cambridge University Press: 225-236.

1991 Glacial deposits of the Isles of Scilly. In Ehlers, J., Gibbard, P. L. and Rose, J., eds., Glacial Deposits in Great Britain and Ireland. Rotterdam, Balkema: 291-300.

Stephens, N. 1970 The West Country and Southern Ireland. In Lewis, C. A., ed., The Glaciations of Wales and Adjoining Regions. London, Longman: 267-314.

Stuiver, M. and Polach, H. A. 1977 Discussion. Reporting of ${ }^{14} \mathrm{C}$ data. Radiocarbon 19(3): 355-363.

West, I. M. 1973 Carbonate cementation of some Pleistocene temperate marine sediments. Sedimentology 20: 229-249.

Yokoyama, Y., Nguyen, H.-V., Quaegebeur, J.-P. and Poupeau, G. 1982 Some problems encountered in the evaluation of annual dose-rate in the electron spin resonance dating of fossil bones. PACT 6: 105-115. 